\title{
季節外生産羊を利用しためん羊発育に及ぼす 環境要因の解析的研究
}

VI長日期における羊毛成長に及ぼす短日処理の影響

\author{
朝日田康司 ·三村 耕 ${ }^{*}$ \\ ( 北海道大学農学部・広島大学水畜産学部) $)^{*}$
}

羊毛の成長は，品種により若干の椲いはあるが，一般に冬季より夏季においてすぐれ，季節的変動 を示すことは古くから認められていた。(Hutchinson \&Wodzicka，19961) 8 ）。いうま でもなく，羊毛成長は栄養状態とは無関係ではないが，1949年 Fergusonら ${ }^{2)}$ は飼料給与レべ ルを一定にした試験を行ない，羊毛成長の季節的変動が栄養とは独立に生ずることを実験的に明らか にし，この主因は環境温度であるとした。

ついでCoop (1953) $)^{1)}$ は光周期説を主張し, 現在までこの両説をめぐり数多くの論議がなされ て来ている。(Ryder \&Stephenson, 1968$)^{17)}$ 。

筆者らは, 本研究の第 4 報 $(1971)^{14)}$ において, 季節外生産羊と正常羊の発育試験と同時に行 なった羊毛の成長に及ぼす環境要因の影響に関する成果を報告した。このなかで，秋〜冬季に絨維の 太さを減じる傾向のあることを指摘し，そしてこの事実は短日と栄養レベルの低下に帰因するものと 考察した。本報告では，4〜6月の長日期に 6 カ月齢以上の季節外生産羊を供試して，羊毛成長に及 ぼす光周期の影響を追究した結果を報告する。

\section{試 験 材 料と方 法}

供試羊 前報までの発育試験に供した季節外生産羊 6 頭を月龄・体重等から第 1 表に示す 2 群に分 けて供試した。6力月龄以上の子羊を用いたのは, 日本コリデール種のフリースはこの月齢までに完 成される(菅井，1953 $3^{18)}$ :三村，1956 $6^{12)}$ ) からである。各羊とも 1 日当り配合濃厚飼料を $300 \mathrm{~g}$ 給与した外, 放牧を含み青草を飽食させた。なお試験期間中の体重の推移も第 1 表に併せて 掲げておいた。

試験処理 1959 年 4 月 24 日から 6 月 22 日に至る 60 日間に， 1 期 20 日間として 3 期を設 け， 1 期ごとに長日飼育および短日飼育を相反覆する反転試験を実施した。群別・期別の試験処理は

Jap. Jour. Sheep Sci. No. 9, 1 8, 1972 .

The Environmental Factors on the Lamb Growth, Analytically

Studies with Extra-Seasonal-Lambs. V. Effect of

Photoperiodicity on Wool Growth.

* Yasushi Asahida and Ko Mimura

* Fac. Agric. Hokkaido Univ. and Fac. Fish. Anim. Husb.,Hiro shima Univ. 
第 1 表 供 試 羊

\begin{tabular}{|c|c|c|c|c|c|c|c|}
\hline \multirow{2}{*}{ 群 } & \multirow{2}{*}{ 羊番号 } & \multirow{2}{*}{ 性 } & \multirow{2}{*}{ 月歯 } & \multirow{2}{*}{ 体重 $(\mathrm{kg})$} & \multicolumn{3}{|c|}{ 各試験期末の体重 $(\mathrm{kg})$} \\
\hline & & & & & 第 I 期1） & 第 II 期1） & 第 III 期 1) \\
\hline \multirow{3}{*}{ A } & $58-1$ & $\hat{o}$ & 10 & 42.4 & 43.1 & 44.3 & 49.0 \\
\hline & $58-5$ & $\hat{o}$ & 7 & 36.2 & 37.0 & 37.4 & 41.0 \\
\hline & $58-7$ & $\hat{o}$ & 6 & 35.8 & 36.9 & 38.4 & 39.0 \\
\hline \multirow{3}{*}{ B } & $58-2$ & q & 6 & 26.6 & 26.8 & 26.7 & 31.5 \\
\hline & $58-3$ & $\hat{o}$ & 10 & 46.8 & 47.9 & 48.9 & 55.0 \\
\hline & $58-9$ & $\hat{o}$ & 6 & 38.8 & 39.9 & 40.7 & 46.0 \\
\hline
\end{tabular}

1）試験処理の項参照

第 2 表の通りである。ここで長日処理は 第 2 表試験 処 理 試験期間の自然日長時間およびその光周 期 ( 1 日約 2 分ずつ延長)をそのまま適 用したものであり, 短日処理は処理開始 日の自然日長時間を人工的に順次 1 日当

\begin{tabular}{|c|c|c|c|}
\hline 群 & 第 I 期 & 第 II 期 & 第 III 期 \\
\hline $\mathrm{A}$ & 短 日 & 長 日 & 短 日 \\
\hline B & 長 日 & 短 日 & 長 日 \\
\hline
\end{tabular}
り約 8 分ずつ短縮（供試羊を暗羊房に収

容）したものである。この短日処理の光周期は自然の 1 年の光周期を約 3 力月に短縮することに相当 する。短日処理から長日処理 (自然光周期) へは 4 日間で移行した。この概略は第 1 図の上方に示寸 通りである。

羊毛成長の測定 各期ごとに, 第 4 報 $^{14)}$ の通り, 右 $\mathrm{mid}-\mathrm{s}$ i de に入墨した一定部位に生産さ れた羊毛について, 純毛生産量・繊維数・繊維の長さ，太さ等を測定した。また一定部位の皮盧面積 も測定した。

結 果

以下項目別に表示寸るが，第 1 図に 1 頭当りの平均值の変化を一括して揭げてある。これらの結果

第 3 表 皮膚面積の変化 (試験開始時に対する百分率)

\begin{tabular}{|c|c|c|c|c|}
\hline 群 & 羊番 号 & 第 I 期末 & 第 II 期末 & 第 III 期末 \\
\hline \multirow{4}{*}{ A } & $58-1$ & 97 & $\begin{array}{lll}117\end{array}$ & 113 \\
\hline & $58-5$ & 107 & $\begin{array}{lll}1 & 0 & 1\end{array}$ & 113 \\
\hline & $58-7$ & $\begin{array}{lll}10 & 0\end{array}$ & 121 & 125 \\
\hline & 平 均 & 104 & 113 & 117 \\
\hline \multirow{4}{*}{ B } & $58-2$ & 108 & 108 & 114 \\
\hline & $58-3$ & 106 & 111 & 1114 \\
\hline & $58-9$ & 101 & 109 & 105 \\
\hline & 平 均 & 105 & 109 & 111 \\
\hline
\end{tabular}


を反転試験法における統計処理の常法に従って計算したところ, 何れの項目についても試験処理によ る有意差は認められなかった。
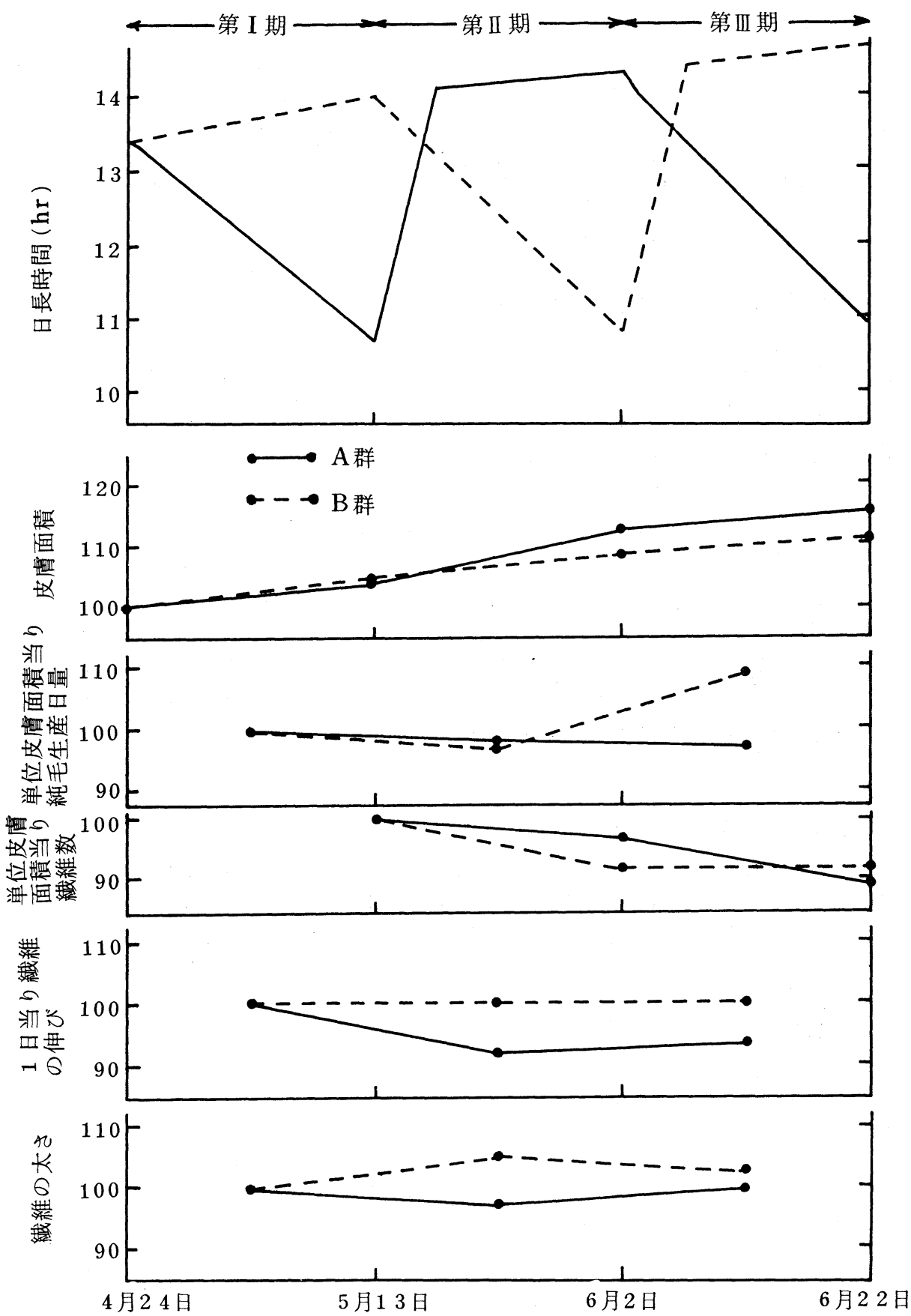

第 1 図試験好理と結果の概要 
皮膚面皘増大率 各 20 日間の試験期における皮膚面積は第 3 表に見られるように, 試験の進行と ともに増大し, 処理の影響は認められない。すなわち, 皮㲊面積増大率は, 第 3 報 ${ }^{13)}$ で論議した如 く体発育を反映するものであり，本試験の光周期処理が発育パターンに影響しなかったと見做してよ い。

純毛生産量 単位皮膚面積当りの污毛生産量から水分・エチルアルコール可溶物・エチルエーテル 可溶物・シュイント・夾雑物量を控除した純毛生産量の変化を第 4 表に示した。表に見られる通り, 両群・各期ともほとんど一定で処理についての変化には一定の傾向は認められない。一定部位におけ る純毛生産量は表示するまでもなく, 第 3 表・第 4 表から推察されるように, 試験の進行につれて増 大の傾向にあった。

第 4 表 純毛生産量の変化 $\left(\mathrm{mg} / \mathrm{day} / \mathrm{cm}^{2}\right)$

\begin{tabular}{|c|c|c|c|c|}
\hline 群 & 羊番号 & 第 I 期 & 第 II 期 & 第 III 期 \\
\hline \multirow{4}{*}{ A } & $58-1$ & 1.08 & 0.84 & 1.04 \\
\hline & $58-5$ & 0.90 & 0.94 & 0.89 \\
\hline & $58-7$ & 0.80 & 0.89 & 0.77 \\
\hline & 平 均 & $0.93\left(\begin{array}{lll}1 & 0 & 0\end{array}\right)$ & $0.89(96)$ & $0.90(97)$ \\
\hline \multirow{4}{*}{$\mathrm{B}$} & $58-2$ & 0.61 & 0.62 & 0.72 \\
\hline & $58-3$ & 0.66 & 0.62 & 0.69 \\
\hline & $58-9$ & 1.05 & 1.00 & 1.10 \\
\hline & 平 均 & $0.77\left(\begin{array}{lll}1 & 0 & 0\end{array}\right)$ & $0.75(97)$ & $0.84\left(\begin{array}{lll}1 & 0 & 9\end{array}\right)$ \\
\hline
\end{tabular}

カッコ内は第 I 期の值に対する百分率

第 5 表 䌦維数の变化 $\left(\right.$ 本 $\left./ \mathrm{cm}^{2}\right)$

\begin{tabular}{|c|c|c|c|c|}
\hline 群 & 羊番号 & 第 I 期末 & 第 II 期末 & 第 III 期末 \\
\hline \multirow{4}{*}{ A } & $58-1$ & 2,973 & 2,443 & 2,480 \\
\hline & $58-5$ & 2,872 & 3,254 & 2,757 \\
\hline & $58-7$ & 2,919 & 2,696 & 2,621 \\
\hline & 平 均 & $2,921\left(\begin{array}{lll}1 & 0 & 0\end{array}\right)$ & $2,798(96)$ & $2,619(90)$ \\
\hline \multirow{4}{*}{ B } & $58-2$ & 2,452 & 2,319 & 2,134 \\
\hline & $58-3$ & 2,042 & 1,890 & 2,027 \\
\hline & $58-9$ & 2,765 & 2,487 & 2,536 \\
\hline & 平 均 & $2,420\left(\begin{array}{lll}1 & 0 & 0\end{array}\right)$ & $2,232(92)$ & $2,232(92)$ \\
\hline
\end{tabular}

カッコ内は第 I 期末の值に対する百分率

繊維数 単立皮膚面積当りの緎維数は, 第 5 表に見られる通り, A 群は試験期が進むにつれて漸減 の傾向にあり，B群は第 II ・III期末で少なくなり両者の差はほとんどなく, 試験処理の影響は認め難 い。 
繊維の長さ 1 日当りの繊維の長さの伸びを第 6 表に示したが，これらの変化にも一定の傾向はな い。

第 6 表 繊維の伸びの変化 $(\mathrm{mm} / \mathrm{d} \mathrm{a} \mathrm{y})$

\begin{tabular}{|c|c|c|c|c|}
\hline 群 & 羊番号 & 第 I 期 & 第 II 期 & 第 III 期 \\
\hline \multirow{4}{*}{ A } & $58-1$ & 0.53 & 0.52 & 0.53 \\
\hline & $58-5$ & 0.51 & 0.45 & 0.50 \\
\hline & $58-7$ & 0.54 & 0.48 & 0.45 \\
\hline & 平均 & $0.53\left(\begin{array}{lll}1 & 0 & 0\end{array}\right)$ & $0.48(91)$ & $0.49(92)$ \\
\hline \multirow{4}{*}{ B } & $58-2$ & 0.54 & 0.50 & 0.53 \\
\hline & $58-3$ & 0.48 & 0.50 & 0.50 \\
\hline & $58-9$ & 0.52 & 0.53 & 0.51 \\
\hline & 平均 & $0.51\left(\begin{array}{lll}1 & 0 & 0\end{array}\right)$ & $0.51\left(\begin{array}{lll}1 & 0 & 0\end{array}\right)$ & $0.51(100)$ \\
\hline
\end{tabular}

カッコ内は第 I 期の值に対する百分率

繊維の太さ 第 7 表に示した通り, 平均値の大きさの順位は $\mathrm{A}$ 群では $\mathrm{I} \geq$ III $>$ II , B 群では II $>$ III $>\mathrm{I}$ である。B群において第 I 期の平均値が最低となったのは $58-2$ 号の $26.7 \mu$ とうう低い值が 大きく影響しているが，この值は試験開始前の栄養状態が悪かったことに㷌因すると解される（第 1 表の体重参照)。いずれにしても, 傾向として論ずれば, 長日期 ( A 群第 II 期, B 群第 I ・ III 期)に 採取した㵶維の太さは小さかったことになる。しかし，各期末に採取した羊毛がその期の処理の影響 を正しく反映しているものと考えることは妥当であろうか。Lyne ら（1970 $)^{6)}$ は, 羊毛成長に 対する処理の影響が皮膚表面上の羊毛にあらわれる期間として, 処理後 20 日を見込むのが安全であ ると述べている。同氏らは成長中の羊毛に取り込まれた $35 \mathrm{~S}$-シスチンが皮膚表面上の羊毛に見出 される日数からこのことを確認しているという。これを事実とするならば，本試験において，各期末

第 7 表 絨維の太さの変化 $(\mu)$

\begin{tabular}{|c|c|c|c|c|}
\hline 群 & 羊番号 & 第 I 期 & 第 II 期 & 第 III 期 \\
\hline \multirow{4}{*}{ A } & $58-1$ & 33.42 & 32.23 & 33.00 \\
\hline & $58-5$ & 28.17 & 28.42 & 28.31 \\
\hline & $58-7$ & 27.40 & 26.63 & 27.61 \\
\hline & 平 均 & $29.66\left(\begin{array}{lll}1 & 0 & 0\end{array}\right)$ & $29.09(98)$ & $29.64\left(\begin{array}{lll}1 & 0 & 0\end{array}\right)$ \\
\hline \multirow{4}{*}{$\mathrm{B}$} & $58-2$ & 26.70 & 31.18 & 29.15 \\
\hline & $58-3$ & 30.94 & 30.20 & 30.48 \\
\hline & $58-9$ & 31.39 & 31.92 & 31.85 \\
\hline & 平 均 & $29.68\left(\begin{array}{lll}1 & 0 & 0\end{array}\right)$ & $31.10\left(\begin{array}{lll}1 & 0 & 5\end{array}\right)$ & $30.49\left(\begin{array}{lll}1 & 0 & 3\end{array}\right)$ \\
\hline
\end{tabular}

カッコ内は第 I 期の値に対する百分率 
に採取した羊毛は，その前の期の処理の影響を受けて成長した羊毛，あるいは少なくとも前期の残効 が大きく表現されているものと考えなければならない。すなわち, 第 7 表の結果から, 短日処理は瀻 度を小さくする傾向があると解す方がより適当と考えられる。

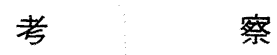

第 1 表の体重の推移に見られるように, 供試羊の発育は 1 頭 $(58-2$ 号)を除いて, ほぼ順調で あった。従って，栄養の影響は一応考虑に入れないでよいであろう。

一般に，正常子羊は約 6 カ月龄までのフリース完成前においては，長日に遭遇するから，このとき の羊毛成長には毛胞発有と長日の効果が影響しているはずである。本試験においては，6〜10 月 齢の季節外生産羊を用いたのであるから, 毛胞発育の関連については無視してよいであろう。本試験 設計の意義の一部もここに存する。この点およびその他の理由から, 結果に見られるように, 供試羊 の月齢の違いも試験処理に対する反応にとくに差異を生じなかったのも予期した通りであった。

一定部位における純毛生産量は, 試験の進行とともに, 皮膚面積の增大と相俟って増大の傾向を示 し，処理の影響は見られなかった。

Hart $\left.\left(1953^{5} ， 1955^{6}\right) ， 1961^{7)}\right)$ は, 長期間の短日処理の結果, 羊毛成長の季節外変動の リズムの振幅が小さくなり, 遂には消失したと述べている。Morris ( 1961$)^{15)}$ は, 夏至と冬至 における日長時間が逆になるように年間の光周期を人工的に逆転させて, 羊毛成長のリズムを 2 年後 に逆転させることに成功している。また Hut chinson (1965) 9 ) は, 自然の年間光周期を人工 照明により 7 カ月に短縮して試験したところ, 羊毛成長のリズムはおおよそこの人工光周期に対応し， 洗上げ羊毛量の最高は最長日長時間の日より短日期に移行して $2 \sim 3$ カ月後に, また最低は最短日長 時間の日から長日期に移行して $2 \sim 3$ カ月後に得られた成績を示している。これらの研究者らは, 羊 毛成長のリズムが気温の年間変動に対応しないことも示している（羊毛成長に対する温度感作の影響 を否定するものではない)。すなわち, 羊毛成長の季節的変動は, 時間のずれはあるが, 本質的に光周 周期によるものであることは明らかで，長日期の光周期が羊毛成長を刺激促進することにあると考元 られる。そして，この生理機構には内分泌機構が関与するのであろう。Ryder \& Stephenson

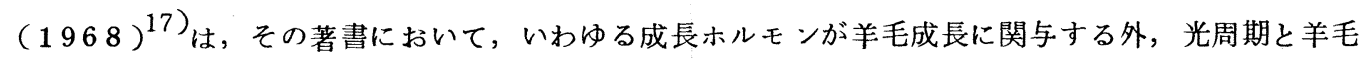
成長に関与寸る内分泌との関係を次のように考えている。すなわち模式的に転記するならば，長日性 光周期にあっては, 光 $\rightarrow$ 目 $\rightarrow$ 脳下垂体前葉一 $(\mathrm{TH}) \rightarrow$ 甲状腺 $\rightarrow+$ イクロキシン分泌 $\rightarrow$ 羊毛成長促進,

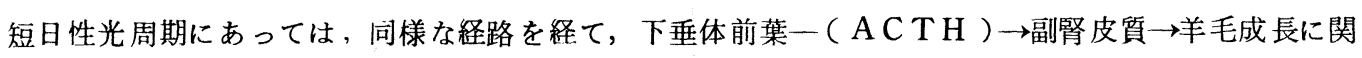
与寸るホルモン分泌の抑制, であるという。本試験は，4〜6月の長日期に実施したものであり，し かも短日処理の期間は 1 期 20 日の短期間であったから, 短日が羊毛成長をとくに刺激促進しない方 向に働くとしても，長日期に優勢な生理機構を抑えるには至らなかったものと考えられる。

羊毛生産量の変動は, 既に第 4 報 ${ }^{14)}$ で詳細に論じたように, 皮膚面積・毛生密度・瀻維の長さ・ 太さ等の変動を含むものである。これらは, 本試験においては, 試験処理に原因すると解される影響 を統計的には受けなかった。しかし，短日処理により繊維の太さが細くなる傾向が指摘されたことに 注目したい，すなわち，短日の影響は羊毛生産量のコンポーネントのうち繊維の太さに最初にあらわ れるであろうことを示唆するものであり，第 4 報の考察と符合する。 
Marston（1955) ${ }^{11 ）}$ は, 繊維の長さと太さが影響を受ける程度は互に独立であると述べてい る。栄養レベルが繊維の長さおよび太さに及ぼす影響について，かって Fraser (1934) ${ }^{3}$ ） は 太さの方が長さより影響を受け易いと報じたのに反し，Galpin（1948) ${ }^{4)}$ はその逆を主張し， Coop (1953) 1) 执びRyder (1956) ${ }^{16)}$ は両者は等しく栄湌の影響を受けると報告してい る。これらの諸研究成果と本試験の成績を対比すると非常に興味深いが, 光周期と羊毛生産量の各コ ンポーネントとの関係については，更に倹討を要するであろう。

要 約

$4 \sim 6$ 月の長日期における $6 \sim 10$ カ月龄の季節外生産羊の羊毛成長に及ぼす 20 日間の短日処理 の影響を追究した。試験期間中単位皮膚面積当りの純毛生産量はほとんど一定で, 処理の影響は認め られなかった。これは, 長日期における光周期が羊毛成長を刺激促進する生理機構が優勢なためと解 された。また, 繊維の太さは短日処理により減じる傾向が示唆された。

この研究は広島大学において行なったものである。協力を睗った島川健次氏, 吉岡勝氏，木村敏彦 氏ならびに附属農場員の各位に深謝する。

\section{参考 文 献}

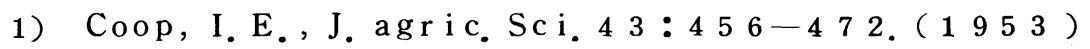

2) Ferguson, K. A., Carter, H. B.\& M. H. Hardy, Aust. J. Sci.Res. B $2: 42-81(1949)$

3) Fraser, A. H. H., Nutr. Abstr. Rev. 4:9-1 $3\left(\begin{array}{llll}1 & 9 & 3 & 4\end{array}\right)$

4) Galpin, N., J. agric. Sci. $38: 303-313\left(\begin{array}{llll}1 & 9 & 4 & 8\end{array}\right)$

5) Hart, D. S., Nature $171: 133\left(\begin{array}{llll}1 & 9 & 5 & 3\end{array}\right)$

6) Hart, D. S., Proc. N. Z. Soc. Anim. Prod., $15: 57-65\left(\begin{array}{lll}1955 & 5\end{array}\right)$

7) Hart, D. S., J.agric. Sci. $56: 235-242\left(\begin{array}{llll}1 & 9 & 6 & 1\end{array}\right)$

8) Hutchinson, J. C. D.\& M. Wodzicka-Tomaszewska, An im. Breed. Abstr. $29: 1-14\left(\begin{array}{llll}19 & 6 & 1\end{array}\right)$

9) Hutchinson, J. C. D., Photoperiodic Control of the Annual Rhythm of Wool Growth. in "Biology of the Skin and Hair Growth"(ed. Lyne, A. G. \& B. F. Short) pp. $565-574$. Angus \& Robertson, Sydney ( $\left.\begin{array}{llll}1 & 9 & 6 & 5\end{array}\right)$

10) Lyne, A. G., Jolly, M. \& D. E. Hollis, J. agric. Sci. $74: 83-90$ ( $\left.\begin{array}{llll}1 & 9 & 7 & 0\end{array}\right)$

11) Marston, H. R., Wool Growth. in "Progress in the Physiology of Farm Animals" (ed. Hammond, J.) Vol. 2, pp. 543-581. But terworths, Lond on ( $\left.\begin{array}{llll}1 & 9 & 5 & 5\end{array}\right)$ 
12) 三村 耕, 広島大学水畜産学部紀要 $1:$ : $2003-2666\left(\begin{array}{llll}1 & 9 & 5 & 6\end{array}\right)$

13) Mimura, K.\& Y. Asahida, J. Fac. Fish. Anim. Husb. Hiroshima Univ. $10: 29-46\left(\begin{array}{llll}1 & 9 & 7 & 1\end{array}\right)$

14) Mimura, K.\& Y. Asahida, ibid. $10: 103-117\left(\begin{array}{lll}19 & 71\end{array}\right)$

15) Morris, L. R., Nature $90: 102-103\left(\begin{array}{llll}1 & 9 & 6 & 1\end{array}\right)$

16) Ryder, M. L., J. agric. Sci. 4 $7: 129-144$ ( 1956 )

17) Ryder, M. L.\& S.K. Stephenson, Wool Growth, pp. $593-625$. Academic Press, London( $\left.\begin{array}{llll}1 & 9 & 6 & 8\end{array}\right)$

18）菅井一男, 日畜会報 $244: 33-35\left(\begin{array}{llll}1 & 9 & 5 & 3\end{array}\right)$

文 献 抄 録 季節外生産羊を利用しためん羊発育に及ぼす環境要因 の解析的研究

IV. 羊毛の成長と環境要因の影響

The Environmental Factors on the Lamb Growth, Analytically Studied with Extra-Seasonal-Lambs IV. Wool Growth and the Effects of Environmental Factors

Ko Mimura and Yasushi Asahida* J. Fac. Fish. Anim. Husb. Hi roshima Univ.10:103-117, 1971.

21 頭の季節外生産羊と 8 頭の正常羊とを 1957 年〜1963 年発育試験し, 生後 1 力年 (雌), 半カ年 (雄) における子羊発育のパターンとこれに及ぼす季節の影響については前報に報告した。こ れと同時に実施した羊毛の成長とこれに及ぼす環境要因の影響に関する成果を本報で報告する。

1. 右 $\mathrm{mid}-\mathrm{side} に 1 \mathrm{~cm}$ 角に入墨した皮膚面より刚取った洗上げ羊毛重量の変化をみると， いずれも生後 $3 \sim 4$ 月間に最高を示した。また春季に急増し，秋・冬季に减少の傾向のみられたこと も興味深い。羊毛生産量は特に皮膚面積, 長さと太さおよび, 絨維数の函数と認められるが, 子羊の 発育初期においては, 密度は当然減少するが, その他は全て増加の相（Brodyの self-accele rat ing phase)にあると考えられ, 冬季生産羊の羊毛成長の変化はこのことを明瞭に示してい る。

2. 同上部位に成長した繊維数は全て 3 月令までに急速に増加し, 以降そのレベルを維持するか増 加したが，初夏生産羊では 6 月令以降すなわち冬〜春季にかけ急減した。

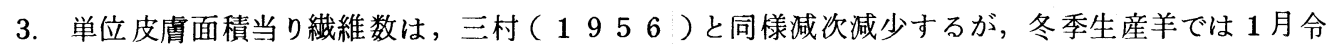
に生時より大となった。羊毛密度は皮膚面積增大率と繊維数増加の両面から娭討を要するであろう。

4. 紻維の太さの变化は，一般に $3 ， 4$ 月令まで増大，4～6 月令に細くなる傾向が認められた。 Lyne ら（１１９７７０）は）暑さは太さを減じるが寒さは太さを減じないと報告している。結果は秋 〜冬季に織維の太さを减じる傾向が認められた。わが国西南暖地の冬季の寒さはきびしくないから， この事実は短日と栄養状態の低下に㷌因寸ることを暗示している。（広大三村 耕） 